\title{
Obesity Behaviors Inside the Body
}

Pramod Stephen

\section{BOOK REVIEW}

Our body has capacity to organize the every cell according to situations. At the time of sorrow, happiness, triedness, playing, reading, writing, sleeping, stooling, urination, eating, drinking, working, thinking, exerciging, walking, dreaming, visiting, wondering, triping fearing, encouraging, accident, hurt eating different kind of food and other situations our body tissue gets changes. If we will take only hurt then we found that if we will get hurt by any things or thorn then body takes automatic action to prevent affected part and connective tissue, sweing tissue, and other tissue barricades the hurt place and they start to heal the place. In the child hood every parent's want that their children become healthy and they gives highly protein and vitamins diets. I have seen many parents' beat their children for eating. Many parents go to doctors to take advice for their children diet and always murmuring for children diets. The actions and reaction takes place in the children tissue and them all tissue become fatty and thick. The structure and texture of natural tissue change design is also disappears. We can see that hardworking people have very strong mussels by seeing them we can know that he or she is hard working people and the body of fatty people is very soft and dull. Its goes from generation to generations and it is taken a epidemic in the world. For control obesity you must see www.diabetescureprocess.com or read the book "Your Health is In Your Mouth"

Patient no. 834/Kol/2007

Copy Right No. 224/10-col

Copy Right No. 4441/10-col

Copy Right no.9554/11-col

Copy Right No.2185/12-col

www.diabetescureprocess.com 